\title{
A música como elemento de conquista em $O$ tempo e o vento
}

Gérson Werlang*

\section{Resumo}

Este artigo propõe a análise da presença da música no romance $O$ tempo e o vento, do escritor Erico Verissimo. O tempo e o vento, um dos grandes romances da literatura brasileira, contempla uma grande variedade de aspectos relacionados à música. Dentre os múltiplos elementos contidos na obra, está a presença marcante da música como mediadora das relações e amálgama das diferenças sociais no sentido de síntese, nas conquistas, amorosas ou não, entre os personagens.

Palavras-chave: Música e literatura. Erico Verissimo. O tempo e o vento.

\section{Introdução}

A trilogia $O$ tempo e o vento representa o ápice da criação literária em Erico Verissimo, e todas as obras anteriores podem ser vistas como um exercício do escritor em busca da maturidade artística necessária para a escrita de seu mais importante romance. Maria da Glória Bordini e Regina Zilbermann destacam o significativo episódio narrado pelo próprio Erico pouco antes de escrever Saga:

Achava-me eu [...] com firme tenção de começar a escrever um massudo romance cíclico que teria o nome de Caravana. Seria um trabalho repousado, lento e denso a abranger duzentos anos da vida do Rio Grande. Começaria numa missão jesuítica em 1740 e terminaria em 1940.

\footnotetext{
Mestre em Música pela University of Miami. Doutor em Letras pela Universidade Federal de Santa Maria. Pós-doutorando em Estudos Literários na Universidade Federal de Santa Maria. Professor do curso de Música da UPF.
} 
Levei a máquina de escrever portátil para a beira de um lago artificial, debaixo de copados pinheiros, decidido a escrever a primeira linha do romance-rio. [...]. Silêncio. Tudo tranquilo. Tudo, menos eu. Não sei que secreta intuição me dizia que não tinha chegado a hora de escrever Caravana (2004, p. 24).

O escritor vinha, portanto, pensando no romance desde os anos 1930, mas amadureceu o projeto até sentir que seria o momento adequado para sua elaboração, o qual somente adveio depois de 1945, após a escrita de Saga e $O$ resto é silêncio, mas também após a queda de Getúlio Vargas, fato que é significativo no desfecho da trilogia e que faz que Erico estenda a narrativa dos planejados 1940 até o ano de 1945 . O primeiro volume da trilogia, $O$ continente, foi escrito entre 1947 e 1948, tendo sido publicado em 1949.

Se o final de $O$ resto é silêncio já anuncia a trilogia (CANDIDO, 1972), muitos elementos constantes nos romances anteriores estarão novamente presentes em O tempo e o vento. A trilogia constitui-se, dessa forma, num estuário que reúne e transfigura em algo novo muitos elementos anteriores, sejam esses elementos temáticos ou estruturais. Dessa forma, também o espectro musical contém aspectos inteiramente novos, assim como repete elementos das obras anteriores, transfigura-os e transcende-os de várias maneiras. Dentre os múltiplos elementos contidos na obra, está a presença marcante da música como mediadora das relações entre os personagens. Assim, este artigo tem como objetivo colocar em evidência a utilização da música como elemento de conquista entre os personagens na construção de $O$ tempo e o vento.

\section{"A fonte"}

Ao lidar com um romance de espectro temporal tão amplo como $O$ tempo e o vento, Erico depara-se com uma abrangência de aspectos musicais que transcende em muito o visitado nos romances anteriores. Mais que isso, o passado musical do Rio Grande do Sul apresenta muitas lacunas históricas, e o escritor teria de refazer intuitivamente muitas conexões, propondo soluções ficcionais para essas lacunas. Por todas essas razões, a questão musical no romance é extremamente bem resolvida, buscando uma variedade ampla de possibilidades sonoras dentro das escassas fontes existentes.

O romance apresenta várias subdivisões que dão a dimensão contrapontística da narrativa. Essa dimensão é multitemporal, na medida em que passado e presente convivem no livro num constante diálogo. A utilização da técnica do contraponto, da qual Erico foi pioneiro no Brasil, em $O$ continente (primeiro volume da trilogia publicado pela primeira vez em 1949), surge de natureza complexa e soma todas as experiências anteriores utilizadas pelo escritor.

Um dos pressupostos teóricos aqui utilizados para a análise está relacionado ao conceito de paisagem sonora, fundamentados por Murray Schafer (2001), 
em seu A afinação do mundo. A paisagem sonora pode ser entendida como o conjunto de sons, musicais ou não, que fazem parte da caracterização de um lugar determinado. Estendemos essa noção para paisagens sonoras individuais, ou seja, o conjunto de sons, musicais ou não, que fazem parte da caracterização de um personagem. Também utilizamos o termo "paisagem musical", em alguns momentos, partindo dos mesmos pressupostos teóricos.

O tempo e o vento, partindo-se da estrutura do seu primeiro volume, $O$ continente, possui várias subdivisões de capítulos, entremeadas pela ação no sobrado, onde a família Terra-Cambará encontra-se sitiada durante a revolução de 1893 (o ano da ação é 1895). Essa subdivisão do episódio entre as várias partes do livro funciona como uma moldura para o romance, cujo início, cronologicamente, dá-se com o episódio de "A fonte", que narra, a partir do ano de 1745 , o desmantelamento das missões jesuíticas. A paisagem sonora de "A fonte" apresenta um espectro amplo que, certamente, exigiu um esforço de pesquisa por parte de Erico para conseguir fechar um todo coerente, também no que diz respeito à parte musical do romance.

Esse espectro envolve os padres jesuítas, particularmente Pe. Alonzo, espanhol de nascimento, os índios e toda a herança musical europeia do período. Temos, inicialmente, a música espanhola, da qual Pe. Alonzo certamente tem influências. Ao recordar sua vida, ele fala das canções de ninar que sua mãe cantava quando criança. Esse personagem aparece como um humanista de formação católica e que tem grande sensibilidade para a música e a arte em geral. Em "A fonte", no entanto, a porção mais significativa de elementos musicais está na música que era feita nas missões e no aspecto da sensibilidade do indígena para esse objeto. Tal aspecto aparece em destaque na obra de muitos historiadores (BRUXEL, 1978; PREISS, 1988), assim como a existência de compositores de formação musical superior, como o Ir. Domenico Zipoli, que publicava suas obras na Europa mesmo morando nas distantes missões jesuíticas (PREISS, 1988). Preiss destaca que "os guaranis [...] desde os primeiros contatos, mostraram muita sensibilidade no que tange à música, e esse foi o principal fator através do qual os missionários, traduzindo a Doutrina Cristã em cânticos no idioma nativo, lograram atraí-los" (1988, p. 20).

Dessa forma, a música adquire um caráter fundamental na vida das missões. Erico esmera-se na descrição do instrumental existente nas $r$ eduções e utiliza todos esses aspectos na narrativa. A listagem de bens que seriam necessários e a relação econômica, que inclui a necessidade de instrumentos musicais, são esmiuçadas:

[...] naquele momento precisavam exportar mais erva-mate e algodão para Buenos Aires, pois quanto mais coisas exportassem mais dinheiro teriam, não só para pagar os dízimos ao rei de Espanha, como também para comprar remédios, instrumentos $\mathrm{e}-\mathrm{oh}$ ! Sim, mais coisas belas para a igreja (VERISSIMO, 1994a, p. 29, grifo nosso). 
Nenhum aspecto da vida, tampouco a rica existência musical das missões deixam de ser salientados por Erico. A vida no local estava embebida de música, tanto dentro da igreja como fora, em procissões, em desfiles, em comemorações:

À frente iam os tocadores de flautas, tiorbas, clarins e tambores; seguiam-se os homens que carregavam nos ombros a imagem do patrono da lavoura; depois vinham os outros índios, cujas vozes, que entoavam um canto sacro, subiam no ar luminoso (VERISSIMO, 1994a, p. 29).

Muitos desses instrumentos são característicos do período. Em 1745, na Europa, vivia-se os anos finais do que mais tarde se convencionou chamar de período Barroco ${ }^{1}$. Quando se inicia o período Clássico, a partir de meados de 1750, muitos instrumentos utilizados no período anterior foram abandonados em prol de outros que se julgava mais apropriados ao novo estilo. Tal foi o caso da tiorba, instrumento típico do Barroco, um grande alaúde utilizado principalmente para acompanhamento de melodias, e que deixou de ser utilizado no período Clássico. Também nesse aspecto, os elementos estão perfeitamente coadunados, os instrumentos citados no decorrer da narrativa estão de acordo com sua época, assim como os estilos musicais citados.

Pe. Alonzo, entre outras atividades, é professor de música. E é durante suas aulas que transparecem as mais significativas reflexões a respeito da música feita naquele local:
Entardecia e Pe. Alonzo terminava sua aula de música. Um dos estudantes tocara ao órgão, havia pouco, um prelúdio. Depois um grupo de instrumentos de arco executara uma sarabanda, e agora o índio Rafael ali estava a tocar na flauta a pavana dum compositor italiano. Junto da janela, Alonzo escutava. Havia no rosto do índio uma inefável expressão de tristeza - mas uma tristeza de imagem asiática - lustrosa, fixa, oblíqua. Parado no meio da sala, de sobrancelhas erguidas, testa pregueada, olhos fechados, ele soprava na flauta, como que esquecido do mundo.

E a voz queixosa do instrumento parecia contar uma história. A melodia ora se desenrolava no ar como uma fita ondulante $-\mathrm{e}$ Alonzo tinha a impressão de ver a linha sonora escapar-se pela janela, avançar campo em fora, acompanhando docemente a curva das coxilhas - ora parecia um lento arabesco noturno. E aquela pavana, composta por um remoto compositor europeu e tocada por aquele índio missioneiro, despertava em Alonzo recordações também remotas. Lembrou-se de sua casa em Pamplona [...]. A melodia serpenteava sobre as coxilhas. Que pensamentos estariam passando pela mente de Rafael? - desejou saber Alonzo. Aqueles índios amavam a música. E com que talento a interpretavam! Que ouvido privilegiado tinham! Havia na redução excelentes organistas, harpistas, corneteiros e cravistas. Tocavam composições difíceis, e até trechos de ópera italiana. Os instrumentos em sua maioria eram fabricados na própria redução pelos próprios índios, dirigidos pelos padres (VERISSIMO, p. 33-34).

Essa descrição da música produzida nas missões encontra eco nos documentos da época. Preiss destaca que "em 1637 o Pe. Ripario escreve ao Provincial de Milão: 'Muitos (indígenas) já sabem muito bem compor música. Podem rivalizar com famosos compositores da Europa'. Usa-se uma grande variedade de instrumentos, sendo o mestre-capela 
um guarani, e não um jesuíta" (1988, p. 21). A variedade de instrumentos encontrados nas missões, reproduzida na narrativa de "A fonte", também aparece frequentemente nos documentos referentes àquela época:

Cita-se como instrumentos o órgão, as violas da gamba em seus diversos tamanhos, os violinos, bombardas, chirimias, dulcianas, flautas, harpas, guitarras e vihuelas (antepassado do violão), alaúdes, trompetes, trompas e tambores. Todos os instrumentos, de fabricação muito cuidada, saíam das oficinas guaranis. Já nos primeiros tempos, o menor dos povos tinha quatro organistas habilitados e músicos que se destacavam por sua excelência como alaudistas, flautistas, cravistas, trompetistas etc. (PREISS, 1988, p. 27).

Evidentemente, a elaboração histórica desta situação deu-se lentamente, daí a singularidade da construção jesuítica nas missões, percebida por Erico:

Padres vindos de além-mar ou de outras missões - pregadores, cartógrafos, músicos, naturalistas, astrônomos, matemáticos, arquitetos - chegavam, ficavam por algum tempo e depois se iam, deixando uma marca de sua passagem: um mapa, um relógio, um órgão, uma imagem, um livro, uma ideia (VERISSIMO, 1994a, p. 37, grifo nosso).

A riqueza e a variedade de aspectos sonoros encontrados na narrativa são, portanto, decorrência das condições históricas; ou seja, a história das missões jesuíticas na América do Sul é, per se, repleta de elementos musicais, dando vazão a uma produção artística posterior que possa reproduzir essa rica paisagem sonora.

Além da riqueza da música instrumental encontrada nas missões, a música vocal ocorre em abundância na narrativa. Cânticos eram entoados em diversas situações, na igreja durante as missas, em procissões, em festividades. No meio onde a natureza ainda se sobrepõe ao homem, uma arte de grande qualidade é produzida:

Quando a procissão passava ao som de cânticos, as aves guinchavam e sacudiam as asas, os animais urravam, e do chão se erguia o perfume de manjericão silvestre esmagado [...]. A catedral reverberava à luz da manhã, como uma fortaleza impávida cujas paredes fossem de ferro em brasa. O ar enchia-se de sinos e das vozes de todas as criaturas de Deus - aves, feras e homens (VERISSIMO, 1994a, p. 39).

A paisagem sonora de "A fonte" inclui, portanto, todo o meio circundante, e a união da música europeia à tendência artística dos índios fundamenta a narrativa, tendência essa que constitui um dos episódios marcantes da história da conquista do Continente de São Pedro.

\section{A música como elemento de conquista}

Há, em O tempo e o vento, um processo cíclico no qual a música desempenha um papel fundamental: ela é o elemento central no processo de conquista que se dá durante toda a narrativa. A história favorece a questão musical, mais especificamente o fato histórico de que os jesuítas conquistaram os índios não a partir da guerra ou da imposição física, mas por meio da música. Esse elemento primordial repete-se ciclicamente no romance: Pedro conquista Ana com mú- 
sica; Capitão Rodrigo conquista Bibiana com seu violão a tiracolo; Luzia enfeitiça Bolívar com sua harpa; Fandango, com seu jeito alegre e nome de ressonâncias musicais, é uma referência para o jovem Licurgo e também um contraponto fundamental para a rigidez de sua avó Bibiana. O papel desempenhado pela música nesse contexto é, portanto, de suma importância.

O processo histórico pelo qual os jesuítas conquistam os índios a partir da música é fartamente documentado e explica o desenvolvimento posterior das missões e sua pujança artística e econômica. Antes da chegada dos jesuítas, já se percebe nos índios habitantes do Brasil uma tendência acentuada para a música, a dança e outras artes. Segundo Preiss:

[...] provavelmente cada tribo tinha seus próprios cantos para os rituais mais diversos, seus instrumentos musicais e suas danças, como ainda hoje acontece com as tribos sobreviventes do interior do Brasil [...] a música instrumental e os cânticos representam um elo com as forças mágicas da natureza, sendo, por isso, o suporte da sociedade tribal. Através dos sons eles alcançam os lugares mitológicos onde está [sic] a fonte da sabedoria e o segredo de viver em harmonia com a natureza (1988, p. 19, grifo nosso).

$\mathrm{O}$ fato de a música ser o suporte $d a$ vida tribal é significativo, e a percepção que desse fato tiveram os jesuítas foi fundamental no desenrolar do processo de conquista dos indígenas e na formação das missões. A narrativa de "A fonte" inicia-se quando esse processo já está consolidado, mas são sentidos os reflexos profundos da importância musical na vida das missões. Ao ouvir os indígenas tocar ou cantar, Pe. Alonzo observa:

A música havia sido e ainda era para os missionários um dos meios mais efetivos de catequização. Tocando seus instrumentos e cantando, eles se haviam aproximado pela primeira vez dos guaranis, desarmando-os espiritual e fisicamente e conquistando-lhes a confiança e a simpatia. No princípio a música fora a linguagem por meio da qual padres e índios se entendiam. E não teria sido porventura a música a língua do $\mathrm{Pa}-$ raíso - o primeiro idioma da humanidade? Por meio da música os jesuítas induziam os índios ao estudo, à oração e ao trabalho. Era ao som de música e cânticos que eles iam para a lavoura, aravam a terra, plantavam e colhiam e era sempre abaixo de música que eles voltavam para a redução ao anoitecer. A música era por assim dizer o veículo que levava aquelas almas a Cristo (VERISSIMO, 1994a, p. 34, grifo nosso).

A conquista do elemento indígena dá-se, portanto, por meio da música, e também a questão étnica aparece refletida no texto. Bruxel (1978) observa que o fato de os índios conquistados serem guaranis é significativo, pois eles apresentavam uma disposição diferente de outras tribos com relação a diversos aspectos. Os guaranis eram semissedentários, ao contrário da maioria das tribos não guaranis, que eram nômades, e "além de caçadores e meladores, eram agrícolas, com alguma plantação de milho, mandioca, batata-doce, abóbora, amendoim e algodão". Buxel complementa, em outra passagem:

Muito mais que o aspecto físico [aos jesuítas interessavam] suas qualidades psíquicas e sociais, que tanto favoreceram sua vida em Redução, e influíram em sua conversão e civilização cristã: o interesse 
pela agricultura, o sentido comunitário, a liderança inconteste do cacique, a propensão para a arte, o dom da imitação (1978, p. 17).

Ainda segundo o mesmo autor, "o dom da imitação permitiu aos índios chegar a um alto grau de perfeição em trabalhos técnicos e artísticos" (BRUXEL, 1978, p. 17). A narrativa de "A fonte" retrata esses aspectos, nos quais a música ocupa um papel central. Quando o menino Pedro nasce na redução em que vive Pe. Alonzo, o mesmo processo musical é repetido. $\mathrm{O}$ menino cresce acompanhado pela educação jesuítica e manifesta os mesmos dons musicais de muitos outros guaranis. Esse talento para a música sedimenta o processo da educação de Pedro, educação que terá um papel primordial na sua relação com Ana Terra.

\section{Pedro e Ana: o canto inverso da sereia}

Ao compararmos a paisagem sonora de "A fonte" com a de "Ana Terra", deparamo-nos com um brutal empobrecimento dos aspectos musicais. Cronologicamente, a narrativa ocorre em torno do ano de 1777, quando o processo de desmantelamento das missões já ia avançado.

A vida de Ana e sua família, perdidos nos fundos de um campo, trabalhando de sol a sol, produz um profundo contraste com a festiva e criativa existência de quem vivia nas missões jesuíticas. Também nas missões trabalhava-se e produzia-se, mas esse trabalho era acompanhado de cânticos, de canções, enfim, não se separava a criatividade dos aspectos mais terra a terra da existência.

O oposto ocorre no rancho onde Ana vive com a família. Por ali nunca se canta, não se ouve qualquer música $\mathrm{e}$ há uma falta generalizada de qualquer elemento criativo. Ana sente falta de uma existência diferente, mas a mão de ferro de seu pai estatiza todas as intenções: sob seu rígido comando, a vida apresenta-se monocromática, e apenas os sons da natureza e do trabalho fazem-se ouvir naquelas paragens. A falta que Ana sente da arte traduz-se no desejo que sentirá por Pedro Missioneiro, quando o índio criado nas missões desde criança e aluno de música de Pe. Alonzo vem parar na fazenda em que ela vive.

A história de Ana Terra, que acontece na segunda metade do século XVIII, apresenta uma continuidade no que tange à questão musical relacionada à conquista: o ciclo repete-se, dessa vez não com jesuítas e indígenas, mas com Pedro Missioneiro e Ana Terra. Desse modo, deixa o âmbito coletivo anterior, substituindo-o pelo âmbito individual. Sai de cena a conquista coletiva dos clérigos sobre os guaranis e entra em cena $o$ ciclo da miscigenação, ocorrida por meio da aproximação amorosa de indivíduos de etnias diferentes, que precisam de um mediador, um elemento de aproximação. Para Ana Terra, esse elemento é a música. 
Nas lonjuras de um fundo de campo, Ana vive com o pai, a mãe e os dois irmãos, Antonio e Horácio. A vida na fazenda é dura, envolvida na faina diária: os homens no campo, as mulheres na lida doméstica. Nessa áspera rotina, destaca-se a severidade não apenas da vida, mas também das pessoas que a rodeiam: o pai Maneco Terra, homem sério, fechado, ignorante, avesso a qualquer forma de arte ou mesmo de lazer, que considera inúteis; os irmãos e a mãe, submissos ao pai e ao marido, não têm coragem ou mesmo possibilidades de fuga daquela vida.

Ana, que nasceu em Sorocaba e veio ainda criança para o sul, guarda lembranças vivas da infância, de um lugar onde "a vida era alegre, havia muitas casas, muita gente, e festas, igrejas, lojas" (1994a, p. 74). Essas lembranças despertam o anseio de um dia, quem sabe, ir embora, deixar aquele lugar. A mãe, no entanto, desfaz suas esperanças: o pai jamais deixaria a fazenda, a terra herdada do avô de Ana, que não a conhecera; a terra fora deixada para Maneco Terra, que veio para o sul e a desbravou aos poucos, com sacrifícios e muito trabalho. Ana reconhece a veracidade da advertência da mãe: o pai jamais deixaria aquela terra. Além disso, aos 25 anos de idade, ela ainda não casara, não tinha namorado. Quando tropas passam pelo local, Ana percebe o olhar dos homens, desconfia que pode ser bela. A passagem do major Rafael Pinto Bandeira pela fazenda desperta sua imaginação, pois ele elogia sua beleza. Sobre o major, ouve histórias: "contava-se que sua estância era muito bem mobiliada e farta, e que tinha até uma banda de música" (1994a, p. 76). A música, inexistente na fazenda, era um luxo apenas vislumbrado através das palavras de estranhos. E Ana gosta de música, que cultiva a sós enquanto lava roupa, longe da presença do pai e dos irmãos:

(Ana) ergueu-se, caminhou para o lugar onde estava o cesto, tirou as roupas para fora, ajoelhou-se, apanhou o sabão preto e começou a lavá-las. Enquanto isso cantava. Eram cantigas que aprendera ainda em Sorocaba. Só cantava quando estava sozinha. Às vezes, perto da mãe, podia cantarolar. Mas na presença do pai e dos irmãos tinha vergonha. Não se lembrava de jamais ter ouvido o pai cantar ou mesmo assobiar (VERISSIMO, 1994a, p. 77).

Essas cantigas são a única companhia de Ana na solidão dos campos e um ponto de ligação com seus anseios mais secretos: ir embora, casar-se. Nas cantigas reside a beleza que falta em tudo o mais: Ana diferencia-se de seu pai, de seus irmãos. A mãe é a única pessoa com quem pode compartilhar seus anseios, embora saiba que ela não reagirá: a vontade de sua mãe permanecerá guardada, reprimida.

A ausência de música é, também, a ausência de esperança, de vida. A monotonia e aridez dos dias são um fardo difícil de carregar naquela casa onde "nunca entrava nenhuma alegria, nunca se ouvia nenhuma música, e ninguém pensava em divertimento" (1994a, p. 79).

É essa a situação que antecede a chegada de Pedro Missioneiro. A roda 
da meada romanesca começa, então, a mover-se, mudando o sentido de todas aquelas vidas como uma força incontrolável, semelhante às tragédias gregas. Pedro traz o elemento que interfere na estagnação, provocando a mudança. Muda as vidas das pessoas envolvidas e provoca sua própria desgraça.

A chegada de Pedro, que a princípio provoca o alvoroço natural do aparecimento de um estranho naquelas lonjuras, logo acomoda situações: Pedro é um bom peão, trabalha em silêncio, come o que lhe dão, sabe domar um potro. Aos poucos, Maneco Terra dobra-se e deixa o estranho ficar. Para Ana, a sua chegada provoca uma mudança, pois sente por Pedro coisas que não consegue entender, sentimentos onde repulsa e desejo confundem-se. Ao ver a tez de Pedro, chama-lhe a atenção o fato de que "era uma face lisa, sem um único fio de barba, e dum bonito que chamava a atenção por não ser comum" (1994a, p. 80). Ao vê-lo, Ana lembra de uma mulher que havia visto quando pequena, em São Paulo. "Diziam que tinha vindo de Paris, era cantora, uma mulher da vida..." (1994a, p. 80). Estranha lembrança, aliar Pedro a essa cantora. Ana sentia que ele possuía algo em comum com "aquela mulher colorida e cheirosa [que] parecia ter feitiço" (1994a, p. 80). Também Pedro possui o componente de atração, o mistério. Ele mesmo evoca o elemento de feitiçaria ao contar a história da Teiniaguá que "já desgració um sacristán” (1994a, p. 98), elemento esse que prediz seu destino e, também, os ciclos de conquista que ocorrem no romance.

Assim, o aparecimento de Pedro estabelece um elo, passado o susto de sua vinda e a estranheza de seu semblante. Ana sente nele algo estranho, mas associa essa estranheza a pessoas que têm um poder. Ao vê-lo tocar a flauta, o elo encantatório completa-se. Ela jamais havia escutado algo assim. Percebe que aqueles sons eram de uma beleza que transcendia qualquer coisa que tivesse conhecido, suas cantigas eram pobres comparadas àquilo. Pedro fora educado, tivera acesso ao conhecimento de coisas que Ana sequer sonhara. Sabia ler, conhecia latim, mas era através da música que essa educação transparecia, manifestava-se da forma mais completa. Pedro um dia chega de manso, como costumava chegar, trazendo o instrumento nas mãos:

- Vosmecê me dá permisso pra tocar alguma côsa?

Maneco Terra pigarreou.

- Tocar?

- Flauta - explicou Pedro. E mostrou a flauta que tinha feito duma taquara [...]. Pedro sentou-se, cruzou as pernas, tirou algumas notas da flauta, como para experimentá-la e depois, franzindo a testa, entrecerrando os olhos, alçando muito as sobrancelhas, começou a tocar. Era uma melodia lenta e meio fúnebre. $\mathrm{O}$ agudo som do instrumento penetrou Ana Terra como uma agulha, e ela se sentiu ferida, trespassada. Mas notas graves começaram a sair da flauta e aos poucos Ana foi percebendo a linha da melodia... Reagiu por alguns segundos, procurando não gostar dela, mas lentamente se foi entregando e se deixando embalar. Sentiu uma tristeza enorme, um desejo amolecido de chorar (VERISSIMO, 1994a, p. 88). 
Um elo de conquista revela-se nas entrelinhas da melodia. Impossível deixar de notar o poder da música nesse momento. Ana deixa-se levar, incondicionalmente. A partir desse dia, entregar-se a Pedro é uma questão de tempo. Tal o poder tem a música sobre as pessoas que mesmo o duro Maneco Terra devolve ao hóspede o punhal que havia lhe retirado quando de sua chegada: o fato de Pedro tocar aquele instrumento serve como um aval de sua idoneidade. Como esse ato dá-se na frente de Ana, parece soar como um sinal de aceite de seu pai a uma possibilidade de futuro. Com o passar dos dias, o encanto permanece, o feitiço posto repete-se ad infinitum: "Na cabeça de Ana soava uma flauta: a melodia que Pedro tocara naquela noite de chuva não lhe saía da memória, noite e dia, dia e noite" (1994a, p. 92).

Não podemos ignorar, também, o caráter fálico da forma do instrumento que Pedro toca. Ana percebe tudo, e como um encantador de serpentes que a todos envolve com seu truque, Pedro consegue, com a mesma ação, conquistá-la e desviar a atenção da família desse fato. Porém, ele é a um só tempo o encantador e o encantado: a conquista de Ana será a sua declaração de morte. Ela se converte na Teiniaguá que destrói o sacristão. De resto, a presença da água onde os dois se amam pela primeira vez fornece outras possibilidades, remete a outras histórias onde a música é elemento de beleza, mas também de destruição. Como a história de Ulisses amarrado ao mastro de sua embarcação para conseguir ouvir o canto das sereias sem sucumbir, a história de Pedro e Ana dá-se como uma inversão da epopeia homérica. Ana é a sereia silenciosa que encontra Pedro à beira d'água, é conquistada por seu canto e provoca a sua morte. Pedro, ao contrário de Ulisses, canta, e a música que conquista Ana provoca a sua perdição.

A conquista ocorre lentamente, o encanto que se estabelece aos poucos cresce até tornar impossível qualquer fuga. Momentos antes de Ana entregar-se a Pedro, o torpor torna-se insuportável:

De longe vinha agora o som da flauta de Pedro. Ana sentia os olhos pesados, a cabeça zonza: seu corpo estava mole e dolorido, como se tivesse levado uma sova. [...]. O som da flauta aumentava-lhe a sensação de calor, de preguiça e mal-estar. - Se ele parasse de tocar era melhor... - murmurou (VERISSIMO, 1994a, p. 95).

A flauta longa, tocada habilmente pelo encantador, hipnotiza sua vítima. $\mathrm{O}$ canto das sereias invertido lança seu sortilégio:

E agora ali no calor do meio-dia, ao som daquela música, voltava-lhe intenso como nunca o desejo de homem [...]. Pensou nos beiços úmidos do índio colados à flauta de taquara. Os beiços de Pedro nos seus seios. Aquela música saía do corpo de Pedro e entrava no corpo dela [...] - Se ele parasse de beijar! exclamou ela. E percebendo que tinha dito beijar em vez de tocar, ficou vermelha e confusa (VERISSIMO, 1994a, p. 96).

Os sons da natureza adquirem qualidades musicais quando o encontro entre Ana e Pedro se aproxima. De noite, quando a família se encontra reunida na frente da casa (mesma noite em que Pedro conta a história da Teiniaguá), Ana 
tem "a impressão de que o lucilar das estrelas acompanha o cricri dos grilos" (VERISSIMO, 1994a, p. 96). Por estes dias, também, Ana começa a ouvir o vento, confirmando sua sensação de que "sempre que me acontece alguma coisa importante, está ventando" (VERISSIMO, 1994a, p. 73).

Os sons da natureza parecem preparar o desígnio que se aproxima, a ordem natural do universo, a continuidade da vida, o ciclo do tempo. Pedro e Ana seguem o curso da natureza, e a conquista que se dá por meio da música é confirmada pelos sons do vento, dos grilos, das cigarras. É impossível escapar desse sortilégio, mesmo que possa haver consequências. "Agora sim ela ouvia o vento" (VERISSIMO, 1994a, p. 101), eis a constatação de Ana na sanga, minutos antes de encontrar-se com Pedro. E o ato consuma-se enquanto os sons da natureza parecem confirmar sua retidão.

Após esse encontro, ela sente culpa, remorsos, mas volta a encontrar-se com Pedro por diversas vezes. Descobre que está grávida e conta a Pedro, pensando em fugir. Pedro vislumbra o seu fim e rende-se a ele, nada faz para impedi-lo: o ciclo do encantamento se fecha. Pedro é assassinado pelos irmãos de Ana.

O assassínio de Pedro muda a vida de todos na fazenda: Ana odeia o pai e os irmãos, mas se resigna à rotina. Mais que isso, o nascimento do filho Pedrinho provoca a consciência absurda do ato: $\mathrm{Pe}-$ dro Missioneiro e Maneco Terra unem-se no corpo do menino. Pedro, em verdade, mudara a vida de todos, e faz-se presente no filho, nas lembranças, até mesmo na surpreendente humanização do pai de Ana. Maneco, que detestava música, é visto certo dia a assobiar: "E num dia seco e limpo de fevereiro todos foram para a lavoura com suas foices. Ana surpreendeu-se vendo o pai assobiar. Era um assobio agudo, cuja melodia, confusa e sincopada, tinha o ritmo do trote do cavalo" (VERISSIMO, 1994a, p. 118).

A presença do menino confirma o tamanho do equívoco do pai e dos irmãos de Ana, em quem o irremediável apenas provoca o desejo de um dia deixar o lugar, destino que se confirma de forma trágica, com o assassínio de Maneco Terra e de todos os que vivem na fazenda, com exceção de Ana, sua cunhada e Pedrinho. Porém, o ciclo da vida já havia cumprido seu curso, e o fruto do amor de Pedro e Ana daria continuidade à família Terra, dessa vez num local diferente, onde a paisagem musical também é outra, a nascente cidade de Santa Fé.

\section{"Um certo Capitão Rodrigo"}

Os elementos relacionados à música presentes em "Ana Terra" repetem-se nas diferentes partes que compõem $O$ tempo e o vento, porém transmutados pelo tempo, pela época e pela personalidade dos personagens. Assim, em "Um certo Capitão Rodrigo", a música é um elemento essencial para que o personagem conquiste Bibiana Terra, filha de Pedro Terra e neta de Ana. 
Assim como Pedro Missioneiro, Rodrigo é um elemento estranho naquela sociedade, um forasteiro que chega num novo meio, que lhe é hostil, e que usa de suas habilidades para conquistar o povo do local. Essa conquista é permeada pela presença da arte, no caso, a música, que leva a que barreiras sociais e o preconceito sejam suplantados.

Toda a cidade havia estranhado a chegada daquele forasteiro a Santa Fé. Vinha usando dolmã militar e bombachas, estava armado e "trazia um violão a tiracolo (VERISSIMO, 1994a, p. 171)". "Aquele violão a tiracolo também lhe inspirava desconfiança” (VERISSIMO, 1994a, p. 174), pensa Juvenal Terra, irmão de Bibiana e o primeiro amigo que Rodrigo faz ao chegar em Santa Fé. Da mesma forma que o pai e os irmãos de Ana, a princípio, desconfiam de Pedro Missioneiro, há a desconfiança a respeito de Rodrigo. A ignorância é conservadora, e a presença da arte é incômoda. A expressão artística invoca a expressão de sentimentos, e a expressão de sentimentos é subversiva, pois na arte tudo é possível.

A sociedade conservadora de Santa Fé, trazida à rédea curta pelo patriarca do povoado, Cel. Ricardo Amaral Neto, desconfia de Rodrigo, mas aos poucos se rende à sua alegria, sua simpatia e à sua habilidade de cantar e tocar o violão. A desconfiança em relação ao indivíduo que toca violão trai um traço histórico: o violão é associado com o castelhano, a guitarra española. Mais tarde, na so- ciedade brasileira, o instrumento será associado à vagabundagem, à desordem. Trata-se de uma visão conservadora podando a expressão artística (social e política) na sua raiz. O domínio torna-se mais fácil quando não há reuniões, não há festas além das asseguradas pela Igreja ou pelo Estado.

Rodrigo é um homem que ama a vida de forma exuberante, revelando suas paixões de forma veemente e clara. Gosta de música e expressa seu gosto:

Quem canta refresca a alma,

Cantar adoça o sofrer,

Quem canta zomba da morte,

Cantar ajuda a viver (VERISSIMO, 1994a, p. 197).

Não é homem de meias palavras, mas sabe se insinuar, ser amistoso quando quer. Bom conversador, sabe contar histórias, e seu vocabulário está repleto de palavras relacionadas a ocasiões festivas e que contêm elementos musicais. Ao falar sobre uma revolução da qual participou, assevera que "o fandango estava armado" (VERISSIMO, 1994a, p. 178, grifo nosso). Ao salientar que o Rio Grande do Sul sempre acaba entrando em guerras, mesmo contra a vontade de seu povo, diz que "nós aqui no Continente sempre acabamos entrando na dança" (VERISSIMO, 1994a, p. 179, grifo nosso). Ao falar do Uruguai, declara "que antes dos orientais conseguirem sua independência tiveram de nos meter no baile" (VERISSIMO, 1994a , p. 180, grifo nosso).

E naquela noite "as gentes de Santa Fé ouviram música de violão na casa de 
Nicolau. E lá de dentro saiu uma bonita voz de homem, cantando modinhas" (VERISSIMO, 1994a, p. 183). Dessa forma inicia-se o processo de encantamento, do feitiço que Capitão Rodrigo lança sobre os habitantes de Santa Fé, mas principalmente sobre Bibiana Terra. Novamente, a música ocupa um papel central na trama. $\mathrm{O}$ ciclo da conquista iniciado pelos Jesuítas sobre os índios e repetido por Pedro Missioneiro sobre Ana volta a acontecer com Capitão Rodrigo, cujo alvo é Bibiana Terra.

O caráter cíclico do romance, tantas vezes evidenciado pela crítica, tem na música uma de suas características, a qual é reforçada pelo sentido vital das conquistas das quais esse elemento faz parte. A música, nesse contexto, sempre une pessoas que vêm de estratos diferentes, de costumes diferentes e que necessitam quebrar barreiras sociais e tabus para tentarem ficar juntas. Ora, esse caráter é o próprio processo de formação do povo sul-rio-grandense, onde a diversidade forma a gênese da sociedade, precisando, justamente, unir opostos muitas vezes tidos como inconciliáveis. Em $O$ continente, esses opostos têm na arte, mais precisamente na música, um ponto de encontro. As canções, o toque da flauta, do violão, ou, mais tarde, com Luzia, da cítara, podem ser identificados como elementos unificadores e pacificadores, atributos tidos por muitos como o significado maior da arte.

Como já acontecera nos primeiros romances de Erico, a música assume um significado inseparável da vida, pois une, aproxima diferenças e propulsiona o ciclo vital. Mesmo que essa união provoque a morte, como é o caso de Pedro e Ana, o ciclo vital segue seu curso, pois a gravidez da personagem garante a continuidade. Da mesma forma, a união de Rodrigo e Bibiana, desaprovada pelo pai da moça, tida como provavelmente malsucedida, com o passar do tempo, acaba formando o clã dos Terra-Cambará, que, pelos traços de coragem de Capitão Rodrigo, será a única família em condições de fazer frente ao clã dos Amarais, primeiros senhores de Santa Fé e que até o surgimento do Capitão traziam o povo da localidade sob o seu domínio. Embora a união de Bibiana e Rodrigo também termine mal, no sentido de que Rodrigo é incapaz de adaptar-se a um tipo de vida contrário à sua índole, o ciclo vital completa-se mais uma vez, e o significado do enfrentamento entre Rodrigo e Bento Amaral, no qual Rodrigo é injustamente ferido por capangas dos rivais, traz à tona a possibilidade de haver uma família que poderia contrabalançar o poderio exercido pelos Amaral em Santa Fé.

\section{"A Teiniaguá"}

Passados 20 anos, Capitão Rodrigo já falecido, seu filho com Bibiana sofrerá sortilégio semelhante ao dos pais. Novamente, a música faz-se presente na história de Bolívar, enfeitiçado pela beleza de Luzia. Como o nome dessa seção do romance reitera, a moça incorpora a 
Teiniaguá, princesa moura que desgraça um cristão, história citada anteriormente por Pedro Missioneiro numa noite na casa de Maneco Terra.

Novamente, o ciclo vital segue seu curso. A absorção das diferenças prossegue, forjando o povo do continente, e a música é novamente mediadora dessas diferenças. Bolívar, assim como seu primo Florêncio, apaixona-se pela filha de Aguinaldo Silva, mas é interessante notar que ambos o fazem enquanto, em Santa Fé, os habitantes nutrem uma desconfiança a respeito da moça. Sobre o pai já pairava todo tipo de conversa a respeito da origem do dinheiro que possuía. Já Luzia "era rica, era bonita, tocava cítara - instrumento que pouca gente ou ninguém ali na vila jamais ouvira - sabia recitar versos, tinha bela caligrafia, e lia até livros" (VERISSIMO, 1994b, p. 335, grifo nosso). Mais uma vez, o espectro da diferença passa pela questão da superioridade da educação. Numa terra de analfabetos, a educação gera desconfiança. Assim como Pedro Missioneiro, Luzia toca um instrumento, e ainda por cima um instrumento exótico, desconhecido, o que só faz aumentar a suspeita. E "quando viam Luzia metida nos seus vestidos de renda, de cintura muito fina e saia rodada; quando aspiravam o perfume que emanava dela", os habitantes de Santa Fé "não podiam fugir à impressão de que a neta do pernambucano era uma mulher perdida" (VERISSIMO, 1994b, p. 335). Evocações da mulher que Ana Terra vira quando criança em Sorocaba, "aquela mulher colorida e cheirosa que parecia ter feitiço?" (VERISSIMO, 1994a, p. 80). Também ela, assim como Luzia, revelava estranhos laços que envolviam a música no rol de seus mistérios. "Diziam que tinha vindo de Paris, era cantora" (VERISSIMO, 1994a, p. 80). Luzia reencarna esses mistérios, e os perfumes, os vestidos, a educação afrontam a rusticidade (e o conservadorismo) das gentes de Santa Fé. "Os rapazes da vila, conquanto se sentissem atraídos por Luzia, concluíam quase todos que ela não era o tipo que desejavam para esposa" (VERISSIMO, 1994b, p. 335). Porém, "Bolívar Cambará e Florêncio Terra", como a seguir o sortilégio da família, "ficaram fascinados por ela" (VERISSIMO, 1994b, p. 335). Dos dois, Bolívar é o escolhido, mas ele tem medo de Luzia e, embora fascinado, não consegue fugir das impressões de seus conterrâneos. E essa impressão mistura-se à culpa pela morte de um homem na guerra, à culpa pela condenação do negro Severino, amigo de infância e que vai ser enforcado graças a seu depoimento no mesmo dia de seu noivado. Tal mescla de culpas lhe dá a sensação de, assim como Severino, caminhar para a morte. Além disso, destacamos a frieza de Luzia, que escolhe a hora e o dia do noivado para que coincidam com o enforcamento de Severino.

O único morador de Santa Fé que consegue ter uma visão distanciada de Luzia é o Dr. Carl Winter. Enquanto os nativos do lugar tentam entendê-la par- 
tindo de uma mistura de preconceitos e desconfiança, ele dispõe das ferramentas necessárias para formar uma opinião abalizada. Carl Winter é um homem culto, nascido e criado na Alemanha, que acaba, por artes do destino, indo parar em Santa Fé. Gosta do lugar e das pessoas, que considera corajosas, fortes e sinceras. Contudo, tem, como estrangeiro, uma visão distanciada da realidade que o circunda e pode emitir juízos críticos a respeito dos moradores do local. Dentro desse contexto, Luzia é diferente e, "ao conhecê-la, Winter ficara todo alvoroçado como um colecionador de borboletas que descobre um espécime raro no lugar mais inesperado do mundo. Tinha-a na mente tal como a vira na festa de seu aniversário, toda vestida de preto, junto duma mesa, a tocar cítara com seus dedos finos e brancos" (VERISSIMO, 1994b, p. 352). Ao vê-la, Winter imediatamente a associa a Melpômene, a musa da tragédia. A incrível mescla de sofisticação, beleza e frieza chama a atenção do médico, que passa a estudá-la com um misto de paixão e distanciamento científico. Além disso, a música os une. Dr. Winter e Luzia são as duas únicas pessoas em Santa Fé com algum estudo formal de música, e o talento da moça faz parte de seu encanto. Winter não apenas se encanta com Luzia, mas também é vítima de um sortilégio: não sabe por que fica em Santa Fé; poderia partir para uma cidade maior, onde houvesse mais desenvolvimento cultural: "Ficar era absurdo, não havia nenhuma razão ponderável para isso. Podia ir para Buenos Aires, ou voltar para qualquer capital europeia onde houvesse teatro, música (que falta ele sentia de teatro e música!)" (VERISSIMO, 1994b, p. 359).

Mais uma vez, a música é um elemento catalisador dos sentimentos. Winter gostaria de partir, mas se deixa ficar, sob o feitiço de Santa Fé. Entretanto, a paixão do médico pela música, reprimida por não partir, manifesta-se em dois pontos-chave: tocar violino e ver Luzia tocar cítara. De certo modo, Winter, assim como Bolívar, fica dependente do sortilégio de Luzia. Uma dependência distante, mas não menos envolvente que aquela que a mesma personagem exerce sobre Bolívar. Claro está que Luzia, como a Teiniaguá da história, tem seu alvo definido. $\mathrm{E}$ Winter percebe isso claramente, durante "os serões semanais no Sobrado, quando Luzia torturava Bolívar com sua indiferença" (VERISSIMO, 1994b, p. 359-360).

A teia do texto é tecida com linhas que levam de um ponto a outro, linhas melódicas, acordes que passam de Luzia a Bolívar e Winter, num ciclo de observações onde a música preenche os espaços (sonoros) da narrativa. Como violinista que é, em tudo lembranças do passado assomam onde o instrumento está presente: no quarteto de cordas que o médico mantinha com amigos quando vivia na Alemanha, evocado pela presença solitária do som de seu violino na noite de Santa Fé; na incompletude reiterada pela percepção da incompre- 
ensão dos habitantes do lugar a respeito dele e da música que toca e que é parte fundamental de sua existência. Para os habitantes da cidade, aqueles sons são despidos de significado.

Pensando nos moradores de Santa Fé e comparando sua vida atual à antiga, Winter observa que "havia em tudo uma rusticidade e uma aspereza que estavam longe de ter o encanto antigo e a madureza das coisas e gentes camponesas da Baviera [...] onde existia uma tradição no que dizia respeito a móveis [...], danças, lendas e canções (VERISSIMO, 1994b, p. 364)". Essa comparação produz uma reflexão a respeito da arte para as pessoas de Santa Fé e, por extensão, do Rio Grande do Sul. "Os homens machos da Província de São Pedro”, reflete Winter, pareciam achar que toda a preocupação artística era, além de inútil, efeminada e por isso olhavam com repugnada desconfiança para os que se preocupavam com poesia, pintura ou certo tipo de música que não fossem as toadas monótonas de seus gaiteiros e violeiros. Como era escassa a música daquela gente! Não passava de uma cantilena que tinha o ritmo do trote do cavalo, um lamento prolongado, pobre de melodia (VERISSIMO, 1994b, p. 364).

Bolívar é vítima desses preconceitos. Ignorante, deixa-se enredar na teia que Luzia tece com seus dedos hábeis de musicista, com sua inteligência cultivada. O único interlocutor real para ela, no entanto, é Winter, com quem pode trocar opiniões a respeito do lugar e das pessoas. Esse diálogo é, também, um diálogo musical, repleto das nuances que a cítara e o violino podem apresentar. Winter depende da música produzida por Luzia. "Infelizmente em Santa Fé Winter tinha de contentar-se com as peças que Luzia dedilhava na cítara ou então com a música que ele próprio produzia" (VERISSIMO, 1994b, p. 364). De certa forma, Luzia apresentava-se para o único membro do público que podia compreendê-la.

Uma vez que participava de grupos musicais no seu país natal, Winter sente falta de interlocutores. "Na Alemanha fizera parte dum quarteto de cordas de amadores, como violinista. (Hans, Hugo, Joseph, onde estais a estas horas?) Reuniam-se nas noites de sábado para tocar Mozart, Beethoven e Schubert, beber cerveja e fumar cachimbo nos intervalos entre um e outro quarteto" (VERISSIMO, 1994b, p. 364). Winter era o interlocutor de Luzia em Santa Fé e, por isso, percebia, de forma mais clara que qualquer outro habitante do lugar, as manobras que ela engendrava. No dia do noivado de Luzia, Winter a achou "perversamente linda". A moça trazia

cravado nos cabelos dum castanho profundo grande pente em forma de leque, no centro do qual faiscava um brilhante. Winter pensou imediatamente na bela e jovem bruxa moura que o diabo, segundo a lenda que corria pela Província, transformara numa lagartixa cuja cabeça consistia numa pedra preciosa de brilho ofuscante [...] Teiniaguá (VERISSIMO, 1994b, p. 371).

No decorrer da festa, Luzia retarda ao máximo o momento de tocar a cítara, não cedendo aos pedidos de seu avô ou 
dos convidados. Espera para tocar no momento em que Severino estaria agonizando na forca: "Vamos, menina, toque um pouco! - tornou a pedir Aguinaldo. - É muito cedo ainda, vovô. Depois eu toco" (VERISSIMO, 1994b, p. 372).

Winter observa que Luzia "tinha uma voz grave e musical, uma voz [...] cujo registro correspondia ao da viola. Era quente, úmida, profunda, veludosa - tão excitante que parecia vir-lhe do sexo e não da boca" (VERISSIMO, 1994b, p. 372). A voz de Luzia também era um dos pontos de atração de Bolívar, que "nunca conseguia explicar a si mesmo por que ficava tão excitado quando a noiva falava. Aquela voz tinha feitiço, punha-lhe uns arrepios no corpo" (VERISSIMO, 1994b, p. 372, grifo nosso). Mais uma vez, o sortilégio familiar apresenta-se de forma musical. O encanto de Luzia impõe-se sonoramente, por meio da cítara, por meio da voz. "Por que não trouxe o seu violino, doutor? - pergunta ela. - Podia tocar um pouco para nós" (VERISSIMO, 1994b, p. 381). A troca dá-se com Winter. Desde já, Bolívar é figura secundária, destinado a ser um joguete nas mãos da futura esposa. E Winter observa como os traços de crueldade de Luzia acentuam-se quando Severino é executado. Só então ela admite tocar, mas toca embebida no prazer do momento, mergulhada num mundo só seu.

Luzia deixou a janela. Seu rosto estava iluminado por uma luz de bondade que a transfigurava. Sentou-se junto do consolo, abriu o estojo de madeira e tirou de dentro dele a cítara. Fez tudo isso com gestos cuidadosos e tranquilos como quem segue um rito. Tirou alguns acordes do instrumento e depois começou a tocar uma valsa brilhante. Winter observava-a, perplexo. A melodia alegre encheu a sala (VERISSIMO, 1994b, p. 385).

A frieza de Luzia espanta Winter, num misto de temor e admiração. Ela toca, a princípio, num frenesi só seu, alheia a todo o movimento exterior, aos convidados, ao noivado. Depois, mais calma, toca e conversa, enquanto olha "para os próprios dedos, como que enamorada deles" (VERISSIMO, 1994b, p. 386).

Em novembro de 1853, Bolívar e Luzia casam-se. A festa é grande para os padrões locais: "Aguinaldo mandou buscar gaiteiros e violeiros de Rio Pardo e Cruz Alta [...]. Dançou-se o fandango à luz duma fogueira acesa no meio do quintal" (VERISSIMO, 1994b, p. 395). O casamento segue em meio às convenções sociais da época, onde a música é simples, direta, sem a presença de cítaras ou violinos.

Depois do casamento, Winter ausenta-se do sobrado por uns tempos. Só tem notícias esparsas de que as coisas não vão bem. No entanto, não fica claro o que não vai bem; as pessoas que trazem as notícias calam-se. A Teiniaguá tece sua teia envolta em mistérios. Só se sabe que "Luzia vivia a ler e a tocar cítara, e isso parecia enervar a sogra" (VERISSIMO, 1994b, p. 428). Bolívar é absorvido pelo mistério da princesa moura: não se sabe o que acontece em sua vida, apenas se intui o rumo inexorável do cristão que perde sua alma. 
Winter, por sua vez, viaja, vai às missões e acostuma-se à vida do lugar. Aos poucos, torna-se um membro efetivo daquela sociedade, nas roupas, nos costumes. Mesmo o violino passa a ser um companheiro não muito frequente, mas que age como um interlocutor na sua solidão. $\mathrm{O}$ violino traz-lhe a lembrança de Luzia, ambos exilados de outras terras, de outros ambientes, de certa forma inadaptados àquele meio:

Enquanto Gregória fazia fogo na cozinha, Carl apanhou o violino e começou a tocar. Tinha os dedos duros de frio. A voz do instrumento pareceu-lhe rouca, e lembrou-lhe, nas notas graves, a voz de Luzia [...]. Carl arranhava no violino um minueto de Beethoven, e quando Gregória apareceu trazendo a chaleira preta de picumã e arrastando os pés de paquiderme, ele teve uma consciência tão aguda do contraste - o minueto e a figura da escrava - que soltou uma risada (VERISSIMO, 1994b, p. 402).

Bolívar e Luzia decidem fazer uma viagem a Porto Alegre. A notícia da viagem a deixa feliz, pois "vivia numa permanente saudade de concertos, festas e teatros" (VERISSIMO, 1994b, p. 428). Tanto Luzia quanto Winter são vítimas da pobreza musical da localidade, são exilados culturais. Ela exulta e "naturalmente começa a tocar cítara, e tocou as peças mais alegres de seu repertório" (VERISSIMO, 1994b, p. 428). Apenas Winter parece compreender a sua alegria: "Confesso que naquele momento tive vontade de beijar a teiniaguá" (VERISSIMO, 1994b, p. 428).

A viagem apressa a deterioração do casamento de Bolívar e Luzia. Ele não consegue compreender nem suportar a mulher, embora a ame. Os traços de sadismo da personalidade da esposa provocam-lhe um mutismo do qual não quer sair e no qual parece fechar-se cada vez mais, encontrando na morte a única saída, não o suicídio real, mas a provocação da própria morte por meio da deliberada afronta aos capangas da família Amaral.

Com a morte de Bolívar, mais uma vez o ciclo se fecha. Em verdade, o ciclo já havia se completado pouco antes, com o nascimento do seu filho com Luzia, Licurgo Cambará. Mais uma vez, a música marca presença no ciclo de conquistas existentes em $O$ tempo e o vento.

\section{Considerações finais}

Em seus mais de 40 anos de vida literária, Erico Verissimo criou uma obra que tem sobrevivido à voragem do tempo e se afirmado como uma das mais relevantes da literatura brasileira. Apesar disso, a humildade com que o escritor sempre tratou tanto sua posição como artífice das letras quanto a importância atribuída a seus livros terminou por obscurecer muitos aspectos relevantes de sua obra.

Partindo do objetivo primeiro deste artigo, mapear a participação da música como elemento de conquista na obra do escritor, percebemos que sua utilização pode ser estendível a múltiplos aspectos, que vão desde o emprego de técnicas musicais até a ilustração sonora de am- 
bientes ou localidades e a caracterização de personagens. A coerência com que Erico Verissimo a trabalhou, somada ao relativo recolhimento a um espaço de sombra em relação a autores que foram saudados como grandes promessas quando de seu surgimento, protegeu $o$ escritor, mas também acobertou a variedade de possibilidades para as quais sua obra se abre, e que o tempo e o trabalho da crítica têm se encarregado de revelar.

\section{Music as an element of conquest in Time and the wind}

\section{Abstract}

This paper proposes the analysis of the presence of music in the novel $O$ tempo $e$ o vento (Time and the wind), by Brazilian writer Erico Verissimo. O tempo e o vento, one of the most important novels of Brazilian contemporary literature, has a variety of aspects related to music. Amongst the multiple aspects presented in this work it is the presence of music as a mediator of the relationships of the characters. This paper aims to evidence one of the elements related to music that appears in the construction of $O$ tempo $e$ o vento, which is the use of music as an element of conquest, having in mind the utilization of musical elements as a medium and amalgam of social differences in the sense of synthesis, amongst the characters.

Keywords: Music and literature. Erico Verissimo. O tempo e o vento (Time and the wind).

\section{Referências}

ALMEIDA, Lélia. A sombra e a chama: as mulheres d'O tempo e o vento. Santa Cruz do Sul, RS: Ed. da UNISC; Porto Alegre: Ed. da Universidade/UFRGS, 1996.

BORDINI, Maria da Glória. Criação literária em Erico Verissimo. Porto Alegre: L\&PM; Edipucrs, 1995.

O continente: um romance de formação? Pós-colonialismo e identidade política. In: GONÇALVES, Robson Pereira (Org.). $O$ tempo e o vento: 50 anos. Santa Maria, RS: UFSM; Bauru, SP: Edusc, 2000. p. 45-67.

Do moderno ao pós-moderno. $\mathrm{Ca}$ dernos de literatura brasileira, São Paulo: Instituto Moreira Salles, n. 16, p. 7-17, 2003.

(Org.). Caderno de pauta simples. Porto Alegre: Instituto Estadual do Livro, 2005.

BORDINI, Maria da Glória; ZILBERMAN, Regina. O tempo e o vento: história, invenção e metamorfose. Porto Alegre: Edipucrs, 2004.

BRUXEL, Arnaldo. Os trinta povos guaranis. Caxias do Su, RS: Educs; Porto Alegre: Sulina, 1978.

CANDÉ, Roland de. Os músicos: a vida, a obra, os estilos. São Paulo: Martins Fontes, 1985.

História universal da música. São Paulo: Martins Fontes, 2001. v. 1.

tes, 2001. v. 2. . São Paulo: Martins Fon-

CANDIDO, Antonio. Erico Verissimo de 1930 a 1970. In: CHAVES, Flávio Loureiro (Org.). $O$ contador de histórias: 40 anos de vida literária de Erico Verissimo. Porto Alegre: Globo, 1972. p. 35-41.

Literatura e sociedade. 8. ed. São Paulo: TA Queiroz, 2000.

CARVALHAL, Tânia Franco. Literatura comparada. 2. ed. São Paulo: Ática, 1992. 
CHAVES, Flavio Loureiro. Erico Verissimo: o escritor e seu tempo. Porto Alegre: Ed. Universidade/UFRGS, 2001.

FRESNOT, Daniel. O pensamento político de Erico Verissimo. Rio de Janeiro: Graal, 1977.

GROUT, Donald Jay; PALISCA, Claude V. Historia de la música occidental. 4. ed. Madrid: Alianza, 1993. v. 1.

GROVE. Dicionário Grove de música: edição concisa. Editado por Stanley Sadie. Rio de Janeiro: Zahar, 1994.

KERN, Arno Alvarez. Missões: uma utopia política. Porto Alegre: Mercado Aberto, 1982.

OLIVEIRA, Solange Ribeiro de. Literaturae música. São Paulo: Perspectiva, 2002.

PREISS, Jorge Hirt. A música nas missões jesuíticas nos séculos XVII e XVIII. Porto Alegre: Martins, 1988.

REAL, Antônio Corte. Subsídios para a história da música no Rio Grande do Sul. 2. ed. Porto Alegre: Movimento, 1984.

SCHAFER, R. Murray. A afinação do mundo. São Paulo: Unesp, 2001.

VERISSIMO, Erico. Saga. Porto Alegre: Globo, 1940.

Globo: 1960.

O resto é silêncio. Porto Alegre:

A música e eu. In: KIEFER, Bruno. Elementos da linguagem musical. 5. ed. Porto Alegre: Movimento, 1987. p. 7-17.

. O continente. 29. ed. São Paulo: Globo, 1994a. t.1.

1994b. t.2.

25. ed. São Paulo: Globo,

WERLANG, Gérson. A música na obra de Erico Verissimo. Passo Fundo, RS: Méritos, 2011.

ZILBERMANN, Regina. A literatura no Rio Grande do Sul. 3. ed. Porto Alegre: Mercado Aberto, 1992. 